\title{
The Differences of Face Culture between China and America in Intercultural Communication
}

\author{
Zhao Ke* \\ Department of Foreign Language, Sichuan University of Science\& Engineering, Zigong City, Sichuan Province,
} China

*Corresponding Author: Zhao Ke, Department of Foreign Language, Sichuan University of Science\& Engineering, Zigong City, Sichuan Province, China

\begin{abstract}
With the development of world economy and culture, people all over the world are closely connected. Because people come from all over the world and they have different cultural backgrounds, there is a situation of cross-cultural communication. When Chinese people communicate with westerners and talk about personal matters, Westerners will feel uncomfortable, which threatens their face. Only when we come across this situation can we realize the importance of "face" and some cross-cultural communication skills.
\end{abstract}

Keywords: Face Culture; Intercultural Communication; Cultural Compare; Cultural Difference

\section{INTRODUCTION}

Face culture is a common phenomenon in Chinese and Western cultures, and it is also a specific reaction of specific cultural values in language under the background of cultural diversity. As a complex social psychology, face culture is involved in the process of cross-cultural communication, and plays an important role in the process of cross-cultural communication. Ron Scollon and Suzanne Wong Scollon once talked about "there is no shameless communication in human communication in the world" [1]. Therefore, it can be said that "face" culture exists in various cultures and is very universal. However, due to different cultural backgrounds, Chinese and American have different views on face.

\section{The Different Face Cultural}

\subsection{The Definition of Face Culture in China}

In China, to give people face is to respect their personality; to lose people's face is to let people's dignity sweep the floor. Mr. Lin Yutang, a famous modern scholar, once pointed out in the book "Chinese", that face is "abstract and unpredictable, but it is the most delicate standard for Chinese to regulate social interaction" [2]. In 1944, Ms. Hu Xianjin, an early Chinese anthropologist studying in the United States, made the first academic research on the concept of face in Chinese culture, and gave a clear explanation. She proposed that "face" refers to "confidence in individual moral personality in society, which covers the unity and integrity of individual moral personality". For the first time, Ms. Hu defined "face" as "the reputation that people have from social achievements, which is the recognition of people's visible achievements". In addition, she also proposed that "face represents a reputation that is widely valued in China, which has been promoted step by step in the course of life. Fame gained by success and boasting is also the reputation accumulated by personal efforts or operation. This is the reason that is reputation "[3].

\subsection{The Definition of Face Culture in America}

In the eyes of Westerners, face focuses on the individual, that is to say, it pays attention to the independent development of human beings and promotes the honorary achievements of personal development. Erwin Goffman, a famous American sociologist, put forward a set of famous face behavior theory in the late 1950s, and comprehensively discussed the concept of "face", that is, face is a ritualized social interaction behavior. In other words, the interaction between social people needs to rely on certain criteria to be able to operate normally. Face represents the individual behavior in line 
with specific social norms, as well as the social support that individuals get from the understanding and application of the concept of face. In 1978, British linguists brown and Levinson further explored the issue of face. Based on the concept of "face" put forward by Goffman, they expanded its concept in depth, calling face "a public self-image that every member of society wants to establish for himself. Through communication with others, this image can be damaged, maintained or enhanced" [4]. This point of view emphasizes that in the process of interpersonal communication, individuals should learn to put themselves in consideration of each other's feelings and face, and be able to take corresponding action strategies to give each other enough face, which are important prerequisites to ensure smooth interpersonal communication and cooperation.

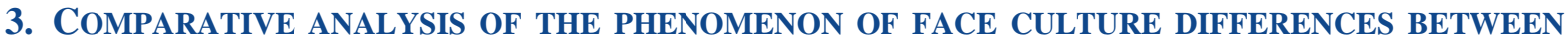 CHINA AND AMERICA}

\subsection{The Difference of Gifts between China and the US}

Chinese people pay more attention to the psychological characteristics of precious and gorgeous gifts. In Chinese culture, gift giving is more to maintain or strengthen the interpersonal relationship with the recipient. From this point of view, the value of gifts is very important. Generally speaking, the value of a gift is positively related to the degree of respect for the recipient, that is, the more valuable the gift is, the more respect it shows for the recipient, the more face the recipient has. While the recipient expresses gratitude and satisfaction for the gift, the giver also gains face. By giving gifts, we not only meet the face of both sides of communication, but also close the relationship between them. In addition, Chinese gift recipients do not immediately open the gift to check, they think it is impolite to do so.

Western gifts are generally not very valuable but practical. In their views, the meaning of a gift is more important than its value. They don't care about the value of the gift. In addition, they give gifts in a more casual way, without too much consideration of their own and the recipient's face. In the selection of gifts, it shows Westerners' practical values. In addition, Western gift recipients will open the gift immediately after receiving it to check and say they like it. In the west, if the recipients don't open the gift immediately, it means they don't like it, which is not polite.

\subsection{Differences between Chinese and American Banquets}

In the west, weddings are sacred and simple. Therefore, weddings are usually held in churches and completed under the auspices of priests. The simple wedding ceremony of western style is closely related to the values of Western individualism. In the eyes of Westerners, marriage is the business of two people, which has nothing to do with others. There are only a few relatives and friends at the wedding banquet, and face issues need not be considered, so the wedding does not need to be more lively and ceremonious. [5]

Most Chinese weddings are very lively and grand. In traditional Chinese culture, the ceremonious degree of wedding is closely related to the family's face and the stability of marriage. In China, only when they have a beautiful wedding can they have face, otherwise they will be laughed at and despised by their relatives and friends. Therefore, one of the important roles of Chinese wedding is to emphasize the stability of marriage through grand and lively ceremony. For the guests, the more people attend the wedding, the more valuable the dowry and dowry of both parties, the more face they have. In addition, the wedding ceremony is also of great significance for connecting people. It's a great honor and honor to be invited to the wedding, because it reflects that the host wants to maintain and enhance the relationship between the two parties. At the same time, being invited to the wedding also makes the families who hold the wedding feast have face.

\subsection{Differences in Toasting between China and the US}

In China, people are used to frequent toasts at various banquets to show respect, enthusiasm and blessing to guests, so the "wine persuasion" culture also emerged. In China, whether it's a gathering of family and friends or a business cooperation, we need to drink together to create a lively and happy atmosphere. If you don't drink or drink little, it is regarded as disrespect and neglect to the guests. If you drink more, it shows that you respect the guests more.

For westerners, wine is just a kind of concoction. When, how and how to drink it are all personal freedom. There is no "respect for doing", and they never persuade wine. In their opinion, frequent 
toasting and persuading is a kind of behavior of forcing others and not respecting others' wishes.

\section{The Reason for the Different FaCe Culture}

The differences between different cultures are due to the different cultural and historical backgrounds, religious beliefs and geographical environment of their respective nationalities. Influenced by cultural heritage. Chinese cultural thought is mainly influenced by Confucius' modesty, courtesy, faith, sensitivity and wisdom. Western culture, on the other hand, is embodied in a word of "struggle", which takes itself as the first when dealing with affairs and communicating with people. Influenced by religious belief, both Buddhism and Taoism in China pay attention to obedience and enjoyment in the afterlife. Both Islam and Christianity in the West stress resistance to oppression. Affected by the geographical environment. The closed terrain of the mainland has formed the Chinese people who are good at summing up the experience and lessons of their predecessors and listening to the opinions of their elders. The west is located in the open sea, with a developed navigation industry, which has formed the westerner's sense of being willing to explore and independent, and less affected by the surrounding environment.

\section{SugGeStions ON HOW TO DEAL WiTH THE CULTURAL DifFERENCES OF FACE BETWEeN CHINA AND THE US}

The different cultural backgrounds between China and the West lead to the concrete differences in their "face" culture. Generally speaking, there are different characteristics between the western "face" culture which emphasizes the negative face maintenance and the Chinese "face" culture which emphasizes the positive face maintenance. These characteristics affect the cross-cultural communication between China and the West. First of all, due to the differences in the "face" culture between China and the West, it is very important to establish the cross-cultural consciousness in the cross-cultural communication. When communicating with westerners, we should adopt a proper attitude of tolerance and understanding and respect their unique "face" culture, which requires us to constantly develop our own ability to deal with cultural diversity flexibly in the process of crosscultural communication. It is an important factor for normal development.

People should have a deep understanding of the differences between Chinese and Western "face" culture, which is not only reflected in the theoretical connotation of "face", but also in the values permeated by "face" culture, the most important of which is to realize that Chinese "face" culture pays more attention to the maintenance of individual or collective positive face with the hope of being recognized and supported by others. While the western "face" culture mainly emphasizes the expression of negative face culture in a more direct way.

Participants in the process of cross-cultural communication need to combine the cultural differences between China and the west, and use the important "face" cultural strategies in cross-cultural communication, such as respect, humor and politeness, to maintain the positive and negative faces of the two sides, reduce the cultural communication barriers caused by the "face" problems, so as to effectively ensure the communication between China and the west, so as to work together to Create harmonious relationships.

\section{CONCLUSiON}

Face culture in China and America shows different ways and reflects the values of different cultures. Generally speaking, face culture in China is mainly collectivism, while face culture in America pays more attention to individualism. It is very important to master face culture and cross-cultural communication methods, and incorrect communication methods are likely to cause conflicts. In the process of cross-cultural communication, face problem is also an important part, but each place has its own unique face culture. If people want to get along well with others, they need to understand and respect tolerance. Face problems in communication should not be underestimated. It is significant to analyze different face problems of different countries in the process of cross-cultural communication.

\section{REFERENCES}

[1] Ron Scollon, Suzanne B K Scollon Intercultrual Communica-tion: A Discourse Approac [M] . Maiden: Blackwell Publisher, 1995: 144.

[2] 林语堂. 中国人( 全译本) [M] . 上海: 学林出版社, 1994:204. 
[3] 刘玲花. 中国人面子心理浅析 $[\mathrm{J}]$ 。华章, 2012, (13) .

[4] 鲁玲萍. 中西文化面子观的差异及其对交际模式的影响 [J] . 武汉理工大学学报, 2014，(3).

[5] 刘盧婷. 中西方面子观差异---以《喜宴》为例 [J] 扬州大学外国语学院, 2019.

Citation: Zhao Ke. "The Differences of Face Culture between China and America in Intercultural Communication". International Journal of Humanities Social Sciences and Education (IJHSSE), vol. 7, no.1, 2020, pp. 121-124. doi: http://dx.doi.org/10.20431/2349-0381.0701013.

Copyright: (C) 2020 Authors. This is an open-access article distributed under the terms of the Creative Commons Attribution License, which permits unrestricted use, distribution, and reproduction in any medium, provided the original author and source are credited. 